\title{
SUPERNATANT LIQUID SAMPLING IN WASTE TANKS (U)
}

\author{
by D. T. Hobbs
}

Westinghouse Savannah River Company

Savannah River Site

Aiken, South Carolina 29808

Other Authors:

\section{RECEIVED \\ FEB - 51993 \\ OSTI}

This paper was prepared in connection with work done under Contract No. DE-AC09-89SR18035 with the U. S. Department of Energy. By acceptance of this paper, the publisher and/or recipient acknowledges the U.S. Government's right to retain a nonexclusive, royalty-free licens, - and to any copyright covering this paper, along with the right to reproduce and to authorize others to reproduce all or part of the copyrighted paper.

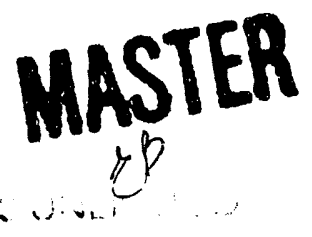




\section{DISCLAIMER}

This report was prepared as an account of work sponsored by an agency of the United States Government. Neither the United States Government nor any agency thereof, nor any of their employees, makes any warranty, express or implied, or assumes any legal liability or responsibility for the accuracy, completeness, or usefulness of any information, apparatus, product, or process disclosed, or represents that its use would not infringe privately owned rights. Reference herein to any specific commercial product, process, or service by trade name, trademark, manufacturer, or otherwise does not necessarily constitute or imply its endorsement, recommendation, or favoring by the United States Government or any agency thereof. The views and opinions of authors expressed herein do not necessarily state or reflect those of the United States Government or any agency thereof.

This report has been reproduced directly from the best available copy.

Available to DOE and DOE contrac:ors from the Office of Scientific and Technical Information, P. O. Box 62, Oak Ridge, TN 37831; prices available from (615) $576-8401$.

Available to the public from the National Technical Information Service, U. S. Department of Commerce, 5285 Port Royal Rd., Springfield, VA 22161. 
WESTINGHOUSE SAVANNAH RIVER COMPANY SAVANNAH RIVER LABORATORY

\author{
WSRC-RP-92-1179 \\ Keywords: Corrosion, \\ Inhibitors, \\ Nitrite, \\ Bydroxide, \\ Nitrate, \\ Radiolysis
}

September 23, 1992

To: D. L. Fish, 773-A

DirJob t5

From: D. T. Hobbs, 773-A

\section{Supernatant Iiquid Sampling in Maste Tanks (U)}

\section{SUMMARY}

Supernatant liquid samples are periodically taken and analyzed for corrosive and inhibiting species concentrations as part of the waste tank chemistry control program. These samples are taken at or near the surface of the waste. This is the preferred location for sampling since the liquid phase at this location is the most corrosive liquid phase in the tank as a result of the highest nitrate to nitrite ratio and the lowest hydroxide concentration.

\section{INTRODUCTION AND DISCUSSION}

High-level nuclear wastes are stored ai the SRS in underground carbon steel tanks. The waste consists of three forms; water insoluble metal oxides and hydroxides (sludge), crystallized water soluble salts (salt cake), and supernatant liquid. Three types of corrosion can occur during the storage and processing of nuclear wastes at SRS; general corrosion, stress corrosion cracking and localized or pitting corrosion.1,2 To limit and/or prevent these types of corrosion, the temperature and composition of the liquid phase are maintained within certain limits. These limits are based on tests which have determined the minimum inhibitor concentrations required to prevent corrosion as a function of the concentration of corrosive species and the temperature of the liquid phase. ${ }^{3}$

In order to determine the concentration of corrosive and inhibiting species in solution, the supernatant liquid in each tank is sampled and analyzed on a periodic basis. Based on the results of this analysis, a decision is made whether to add inhibitor(s) to the tank contents. This sample is taken at or near the surface of the liquid phase. Samplers have also been developed to take samples at variable depths. However, these samplers are not routinely used in the tank chemistry control program. 
The concentration of chemical species in the high-level waste stored at the SRS can vary within the liquid phase due to radiolytic reactions, chemical reactions, and additions of waste having varying compositions. In order to assess whether the composition of the liquid phase of $\mathrm{HLW}$ is adequately inhibited, samples of the supernatant liquid are taken and analyzed on a periodic basis. Since the composition of the liquid phase can vary within a tank, the selection of the sampling location(s) must include that which would exhibit the most corrosive solution.

Nitrate is converted into nitrite by radiolysis.4.5 Nitrite is an effective corrosion inhibitor. With the exception of the ITP process, there are no reactions which rapidly consume nitrite during storage and processing of HLW. ${ }^{6}$ Thus, as the waste age:s, the nitrate concentration decreases and the nitrite concentration increases. As a result, the corrosivity of the waste decreases. Thus, the most corrosive solution in a waste tank would be that: which has been most recently added to the tank since the ratio of nitrate to nitrite would be highest in this fraction. Since this fresh waste would be at the top of the tank, the preferred sampling location would be at or near the top of the waste stored in the tank.

\section{Sludge}

Settled sludge consists of about $20 \%$ metal oxide and hydroxide solids and $80 \%$ supernatant liquid. Because of the high concentration of fission products in the sludge solids, the absorbed dose of the supernatant liquid in the settled sludge is greater than that in the supernatant liquid above the sludge. Therefore, the nitrite concentration is higher and the nitrate concentration is lower in the settled sludge region than in the supernatant liquid above the sludge which was originally part of the same waste transfer into the storage tank.

\section{Supernatant Iiquid}

All waste tanks are actively ventilated with air to prevent the buildup of flammable vapor mixtures of hydrogen.? Alkaline solutions such as the supernatant liquid in the waste storage tanks are known to absorb carbon dioxide from air, which reacts with the hydroxide in solution producing bicarbonate and carbonate species. 8 No attempt is made to exclude carbon dioxide from the air which passes through the storage tanks. Thus, carbon dioxide is continuously absorbed by the waste. Absorption of the carbon dioxide continues until the partial pressure of carbon dioxide over the solution equals that of the air entering the tank.9

For a relatively stagnant tank which has not reached steady-state conditions with respect to the absorption 'of carbon dioxide, a concentration gradient in hydroxide would develop extending down from the liquid/vapor interface to the bottom of the tank. Thus, 
the lowest hydroxide concentration in the tank would occur at the supernatant liquid/vapor interface. This location would thus have the greatest possibility of being corrosive, and would be the preferred sampling location to ensure that a sufficient amount of hydroxide is present to prevent attack of the tank steel.

\section{Salt Cake}

Salt cake is produced by cooling evaporated supernatant liquid. During evaporation, the supernatant liquid is concentrated a factor of about three. Thus, the salt concentration in the uncooled liquid is increased by a factor of about three. Upon cooling, salts crystallize, according to their solubility limits. Sodium hydroxide has the greatest water solubility of the major salts and thus, the cooled supernatant liquid is enriched in hydroxide. After allowing the salts to settle, the supernatant liquid is decanted leaving a small layer of supernatant liquid covering the salts. This process is repeated until the tank is filled with salt cake.

The salt cake is comprised of crystalline salts and interstitial supernatant liquid. The major salt components in the crystalline solids are the sodium salts of nitrate, nitrite, aluminate and hydroxide. The interstitial liquid is enriched in hydroxide because of the higher solubility of sodium hydroxide. As carbon dioxide is absorbed and reacts with the hydroxide in solution, it would be replenished from hydroxide in the crystalline salts. As discussed earlier, the minimum hydroxide concentration in the liquid phase would occur at the liquid/vapor interface, and thus sampling at this location would represent the most corrosive composition in the tank.

Due to the absorption of atmospheric carbon dioxide, the relative younger age, and the decreased concentration of fission products, the liquid phase at the top of a waste tank will exhibit the highest nitrate to nitrite ratio and the lowest hydroxide concentration. This combination of higher nitrate to nitrite ratio and lower hydroxide concentration results in the liquid phase at this location being potentially more corrosive than lower regions. Thus, this location is the preferred sampling location in order to determine the need for additional corrosion inhibitor(s). 


\section{REFERENCES}

1. R. S. Ondrejcin and J. A. Donovan to A. S. Jennings, "Recommended Limits for Temperature and Compositions of Wastes in Tanks," DPST-75-531, December 17, 1975.

2. R. S. Ondrejcin, "Prediction of Stress Corrosion of Carbon Steel by Nuclear Process Liquid Wastes," DP-1478, August, 1978.

3. DSPST-241-5.01, "Limitations of Waste Tank Contents," February 27, 1992 .

4. M. L. Hyder, "The Radiolysis of Aqueous Nitrate Solutions," J. Phys. Chem., 69, 1858 (1965).

5. N. E. Bibler, "Curium-244 $\alpha$ Radiolysis of Nitric Acid. Oxygen Production from Direct Radiolysis of Nitrate Ions," J. of Phys. Chem., 78, 211 (1974).

6. D. D. Walker, "Benzene Distribution in Product Streams From In-Tank Processing," DPST-86-390, January 15, 1987.

7. DPSTSA-200-10, Sup1-18, "Safety Analysis - 200 Area Liquid Radioactive Waste Handling Facilities," August, 1988.

8. D. T. Hobbs, "Absorption of Carbon Dioxide in Waste Tanks", DPST-87-596, September 3, 1987.

9. D. T. Hobbs and R. M. Wallace, "Hydroxide Depletion in Waste Tanks by Reaction with Carbon Dioxide", DPST-85-846, October 14, 1985.

Cc:
T. M. Monahon, 703-H
R. A. Scaggs, 703-H
T. C. Temple, 703-H
B. L. Lewis, 703-
M. W. Lewis, 703-A
T. C. Hsu, 704-T
M. C. Chandler, 703-H
G. K. Georgeton, 703-H
P. D. d'Entremont, 703-H
J. Pike, 703-H
R. T. Begley, 773-A
L. M. Papouchado, 773-A
W. L. Tamosaitis, 773-A
T. L. Capeletti, 773-A
C. F. Jenkins, 773-A
D. D. Walker, 773-A
J. E. Marra, 773-A
P. E. Zapp, 773-A
J. I. Mickalonis, 773-A
B. J. Wiersma, 773-A
G.



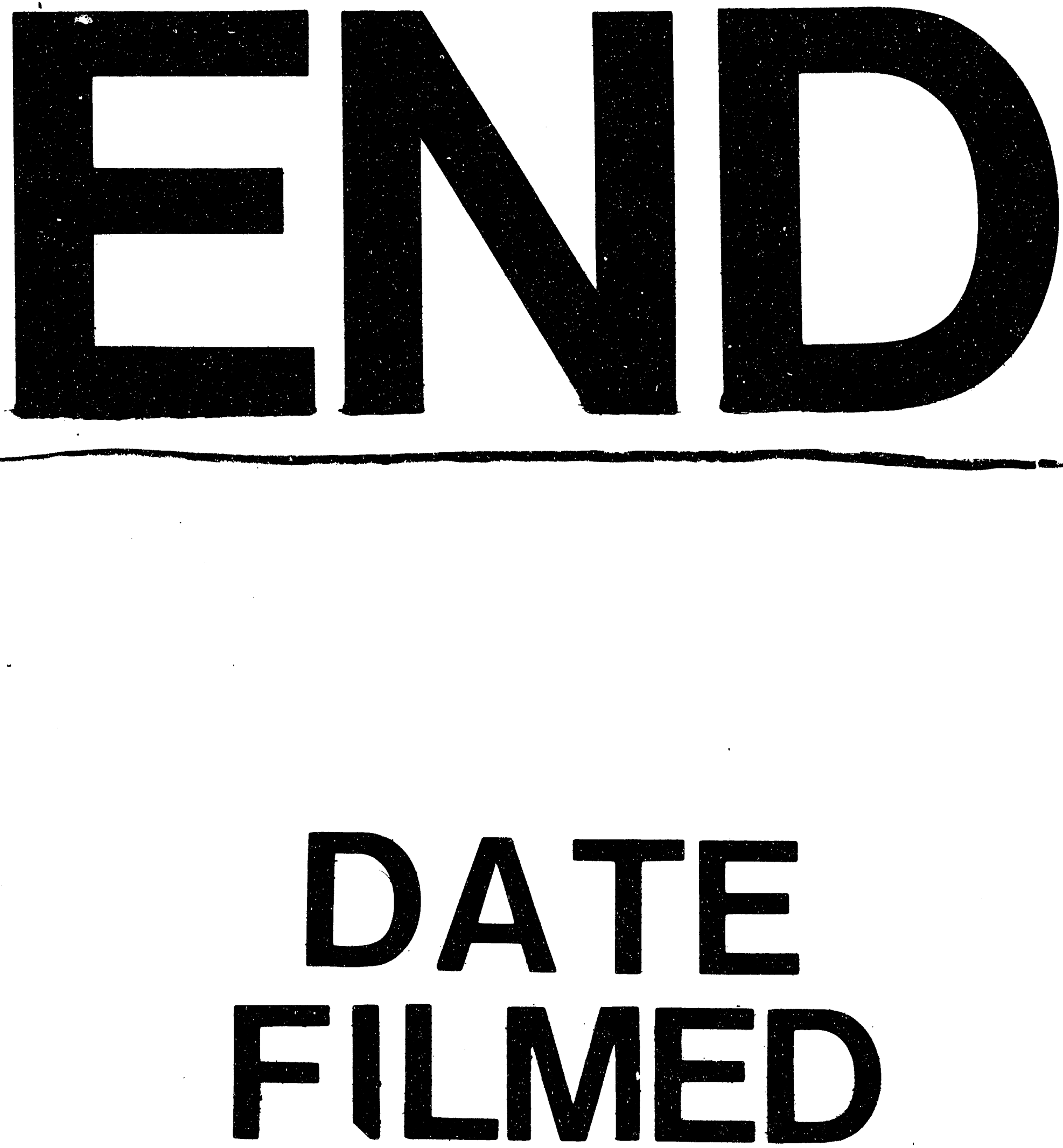

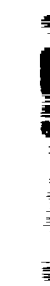

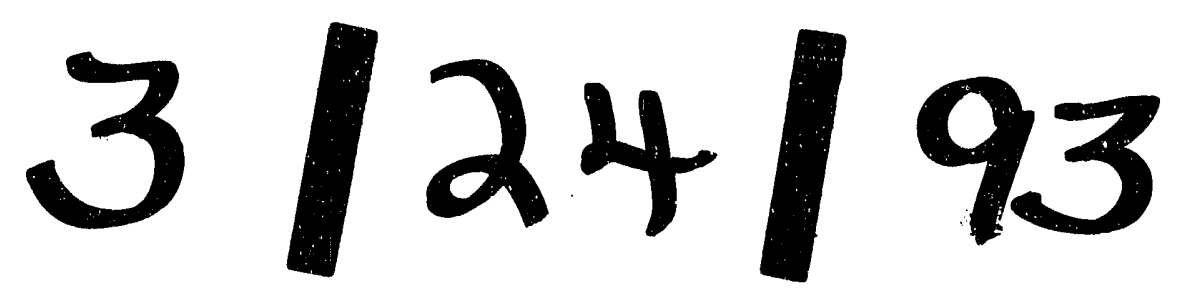


